\title{
elsevier_AGEE_5362
}

\section{Land-use changes from arable crop to kiwi-orchard increased nutrient surpluses and accumulation in soils}

Yongli Lu

Zhujun Chena,b

Tingting Kang

Xiaojia Zhang ${ }^{a, b}$

Jessica Bellarby ${ }^{c}$

Jianbin Zhou $\mathrm{u}^{\mathrm{a}, \mathrm{b}, *}$

jbzhou@nwsuaf.edu.cn

jianbinz@hotmail.com

aCollege of Natural Resources and Environment, Northwest A\&F University, Yangling, 712100 Shaanxi, China

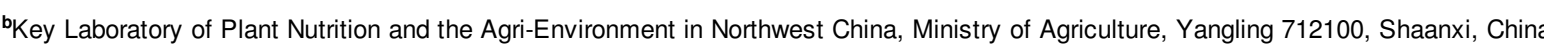

'Lancaster Environment Centre, Lancaster University, Bailrigg, Lancaster LA1 4YQ, UK

*Corresponding author. Present address: Taicheng Road, 3\#, Yangling, Shaanxi 712100, China.

\section{Abstract}

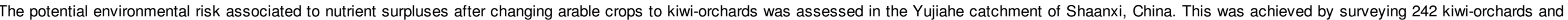

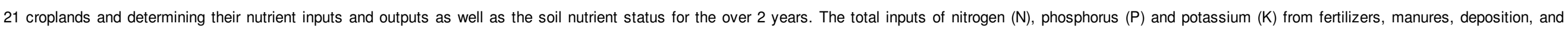

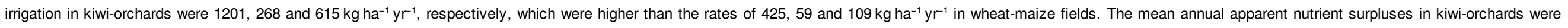

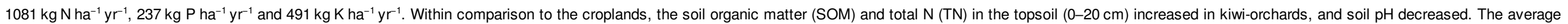

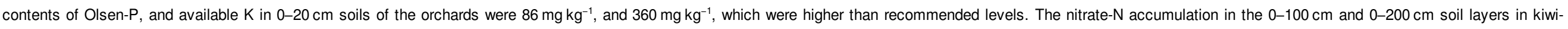

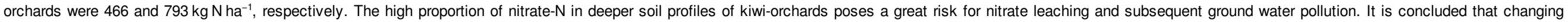
arable crops to kiwi-orchards increased the environmental burden of the catchment due to excessive fertilizer application in kiwi-orchards.

Keywords: Kiwi-orchard; Nutrient input; Soil nutrients; Nitrate accumulation

\section{Introduction}

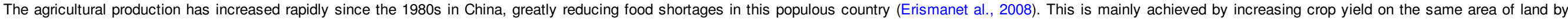

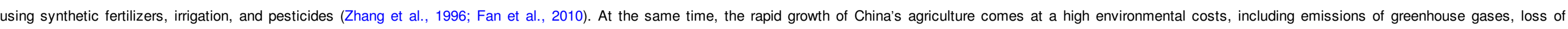

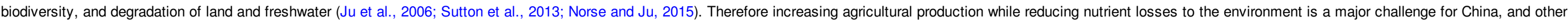
countries with a similar situation.

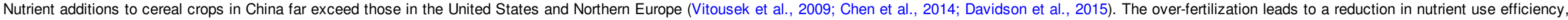

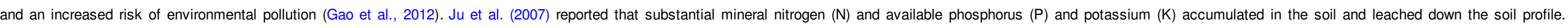




\section{elsevier_AGEE_5362}

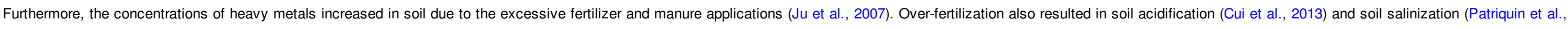
1993; Gao et al., 2012), which may adversely affect plant growth, production, and crop quality.

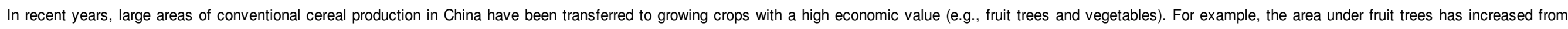

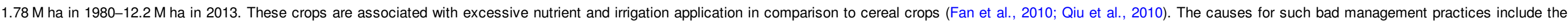

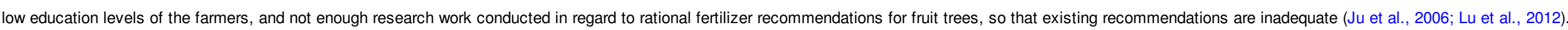

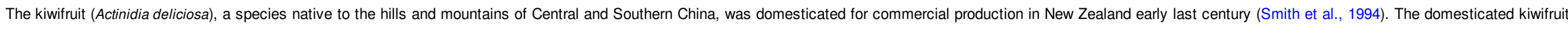

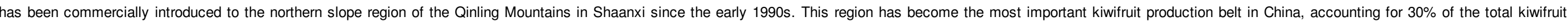

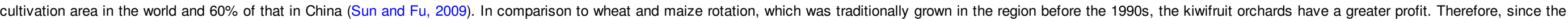

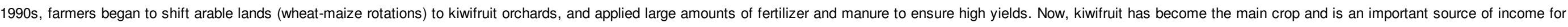
local farmers. Therefore it is important to understand the effects of land-use change from arable land to kiwi-orchards on the soil nutrient budget and their potential associated environmental risks.

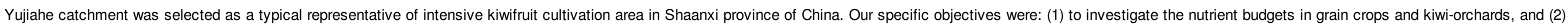
to evaluate the potential environmental impacts after converting the cropland to kiwifruit orchards.

\section{Materials and methods}

\subsection{Site description and cropping systems}

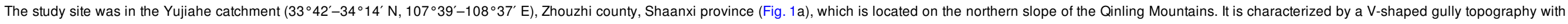

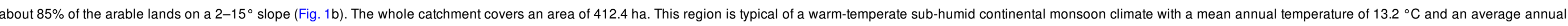
precipitation of $713 \mathrm{~mm}$ (from 1957 to 2012), with 61-84\% occurring between July and September.

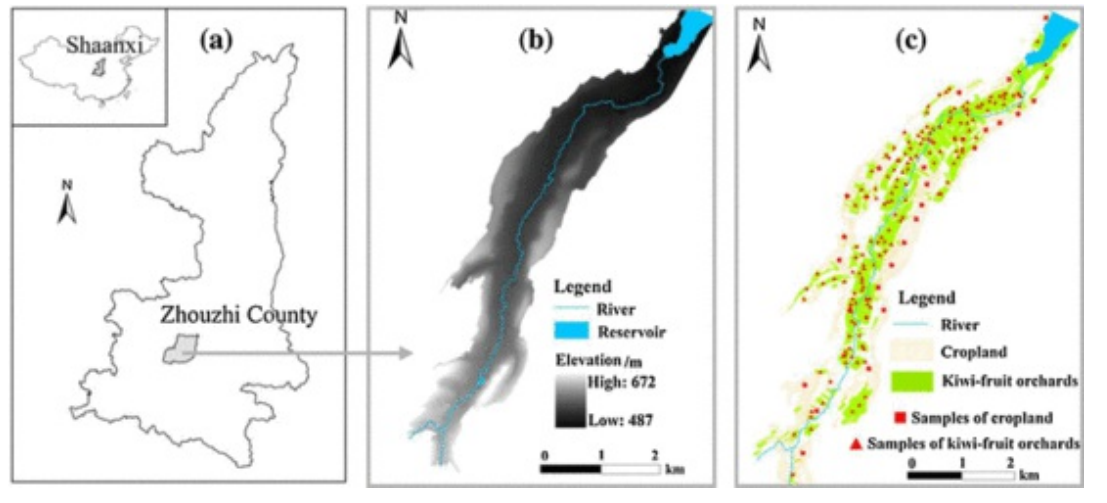

Fig. 1 The location (a), digital elevation model (DEM) (b), land use status, and survey sites of the two cropping systems (c) in Yujiahe catchment.

alt-text: Fig. 1

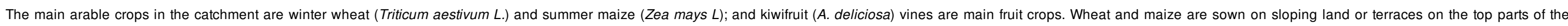

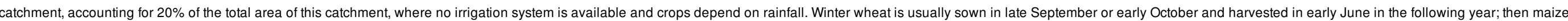

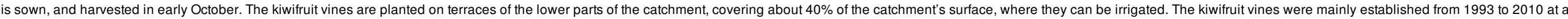

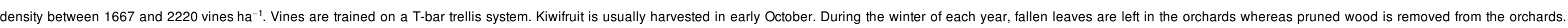

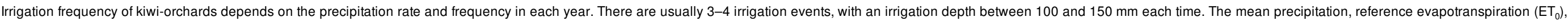

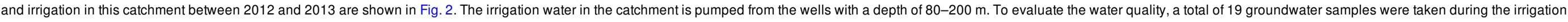




\section{elsevier_AGEE_5362}

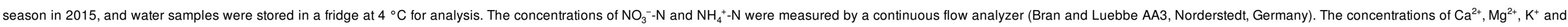
$\mathrm{Na}^{+}$were measured by an atomic absorption spectrophotometer (Z-2000, ICP-AES). The information about water quality is shown in Table 3.

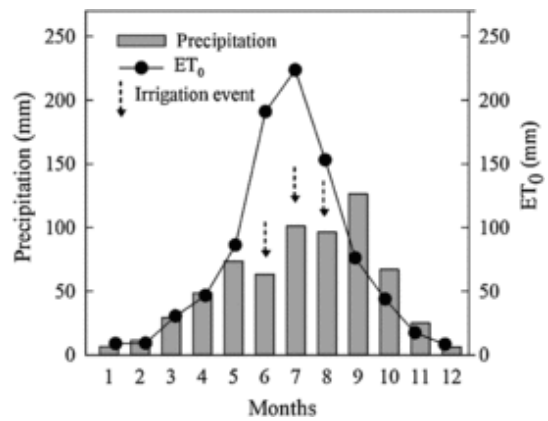

Fig. 2 Mean monthly precipitation, reference evapotranspiration ( $\left.\mathrm{ET}_{0}\right)$, and irrigation amount over 2012 and 2013 years in this catchment.

alt-text: Fig. 2

\subsection{Survey and sampling}

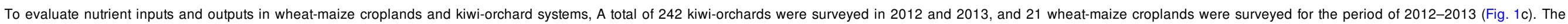

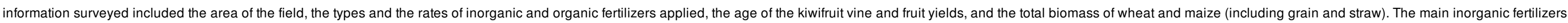

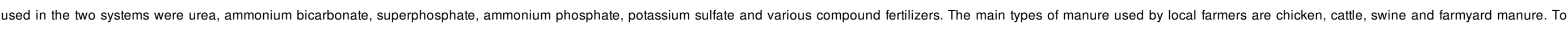

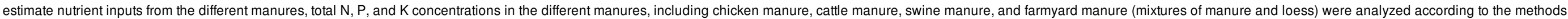
of Gao et al. (2012). The nutrient contents of the manures in this study are listed in Table 1.

Table 1 Nutrient concentrations (with standard deviation in brackets) of the different manures (dry weight).

\section{alt-text: Table 1}

\begin{tabular}{|c|c|c|c|}
\hline Manure & $N\left(g_{N ~ k g}-1\right)$ & $P\left(g P g^{-1}\right)$ & $\mathrm{K}\left(\mathrm{g} \mathrm{K} \mathrm{kg}^{-1}\right)$ \\
\hline Chicken manure $(n=6)$ & 25.30 & $11.06(2.75)$ & $16.18(0.96)$ \\
\hline Cattle manure $(n=6)$ & $16.28(2.93)$ & $4.54(0.36)$ & $12.78(1.97)$ \\
\hline Swine manure $(n=6)$ & $24.65(7.82)$ & $8.83(0.65)$ & $17.01(7.17)$ \\
\hline Farmyard manure $(n=7)$ & $2.17(0.97)$ & $0.85(0.49)$ & $5.64(1.26)$ \\
\hline
\end{tabular}

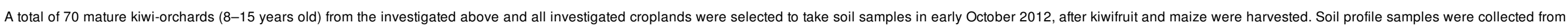

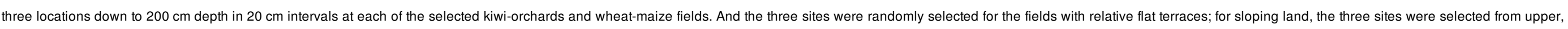
central and bottom part of the fields. The triplicate samples were mixed to obtain a composite sample from each soil depths and placed in labelled plastic bags, sealed and stored immediately at $4{ }^{\circ} \mathrm{C}$.

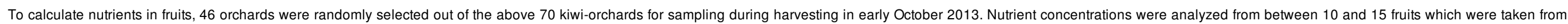

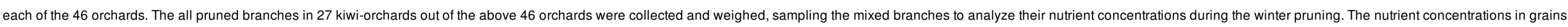
and straws of wheat and maize were from a field experiment of ours in the catchment during the 2012-2013.

\subsection{Sample analyses}

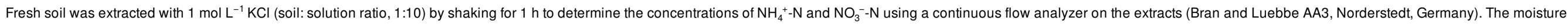




\section{elsevier_AGEE_5362}

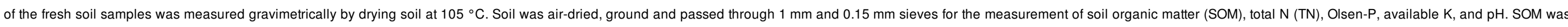

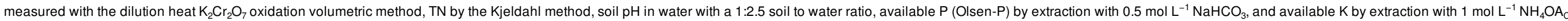

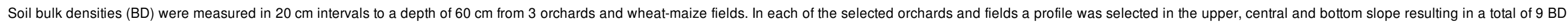

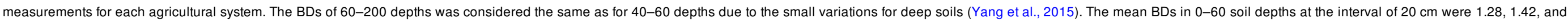
$1.43 \mathrm{~g} \mathrm{~cm}^{-3}$ for the kiwifruit orchards, and $1.37,1.45$, and $1.47 \mathrm{~g} \mathrm{~cm}^{-3}$ for the wheat-maize field.

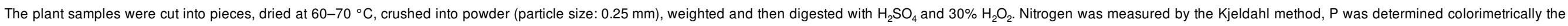
ammonium-vanadate-molybdate method (Gericke and Kurmies, 1952), and K was measured by Atomic absorption spectrophotometer (Z-2000, ICP-AES). The nutrient concentrations of plant materials are shown in Table 2 .

Table 2 Nutrient concentrations (with standard deviation in brackets) of different plant organs in the two systems (dry weight).

alt-text: Table 2

\begin{tabular}{|c|c|c|c|c|c|c|}
\hline \multirow[t]{2}{*}{ Nutrients } & \multicolumn{2}{|c|}{ Kiwifruit vine } & \multicolumn{2}{|c|}{ Winter wheat } & \multicolumn{2}{|c|}{ Summer maize } \\
\hline & Fruit (\%) & Pruning (\%) & Grain (\%) & Straw (\%) & Grain (\%) & Straw (\%) \\
\hline Nitrogen $(\mathrm{N})$ & $0.86(0.10)$ & $0.76(0.09)$ & $2.54(0.15)$ & $0.61(0.05)$ & $1.38(0.03)$ & $0.75(0.08)$ \\
\hline Phosphorus (P) & $0.29(0.04)$ & $0.10(0.04)$ & $0.25(0.06)$ & $0.024(0.007)$ & $0.32(0.06)$ & $0.16(0.02)$ \\
\hline Potassium (K) & $1.43(0.18)$ & $0.69(0.11)$ & $0.40(0.03)$ & $0.86(0.12)$ & $0.31(0.02)$ & $0.79(0.09)$ \\
\hline
\end{tabular}

\subsection{Calculation of nutrient inputs and outputs}

Nutrient apparent balance in soil was calculated by the following formula (Ju et al., 2006):

Apparent nutrient surplus = input components (chemical fertilizer + manure + seed + deposition + irrigation) - output components (nutrient removal by straw and grain).

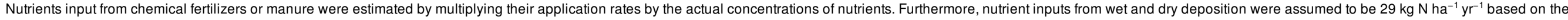

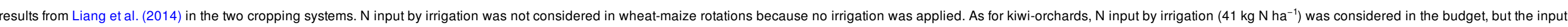
of $\mathrm{P}$ and $\mathrm{K}$ were ignored because of their low contents (Table 3). $\mathrm{N}$ input from wheat and maize seeds was $5.40 \mathrm{~kg} \mathrm{ha}^{-1}$, while the amount of $\mathrm{P}$ and $\mathrm{K}$ were negligible (Table 2).

Table 3 The characteristics (with standard deviation in brackets) of the 19 samples of irrigation water from deep well (depth of $80-200 \mathrm{~m}$ ) in this catchment.

alt-text: Table 3

\begin{tabular}{|c|c|c|c|c|c|c|c|c|c|}
\hline $\begin{array}{l}\text { Well depth } \\
(\mathrm{m})\end{array}$ & $\begin{array}{l}\mathrm{NO}_{3}^{-}-\mathrm{N} \\
(\mathrm{mg} / \mathrm{L})\end{array}$ & $\begin{array}{l}\mathrm{NH}_{4}{ }^{+}-\mathrm{N} \\
(\mathrm{mg} / \mathrm{L})\end{array}$ & $\begin{array}{c}\mathrm{PO}_{4}{ }^{3-}-\mathrm{P} \\
(\mathrm{mg} / \mathrm{L})\end{array}$ & $\begin{array}{c}\mathrm{K} \\
(\mathrm{mg} / \mathrm{L})\end{array}$ & $\begin{array}{c}E C \\
(\mu \mathrm{s} / \mathrm{cm})\end{array}$ & $\begin{array}{c}\mathrm{Ca} \\
(\mathrm{mg} / \mathrm{L})\end{array}$ & $\begin{array}{c}\mathrm{Mg} \\
(\mathrm{mg} / \mathrm{L})\end{array}$ & $\begin{array}{c}\mathrm{Na} \\
(\mathrm{mg} / \mathrm{L})\end{array}$ & $\mathrm{pH}$ \\
\hline 80-200 & $\begin{array}{l}7.32 \\
(6.01)\end{array}$ & $\begin{array}{l}0.10 \\
(0.04)\end{array}$ & $\begin{array}{l}0.081 \\
(0.035)\end{array}$ & $\begin{array}{l}1.15 \\
(0.53)\end{array}$ & $\begin{array}{l}544.26 \\
(122.97)\end{array}$ & $\begin{array}{l}83.56 \\
(21.01)\end{array}$ & $\begin{array}{l}16.10 \\
(3.79)\end{array}$ & $\begin{array}{l}18.46 \\
(1.26)\end{array}$ & $\begin{array}{l}8.10 \\
(0.40)\end{array}$ \\
\hline
\end{tabular}

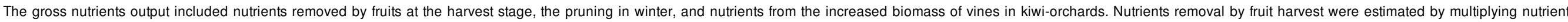

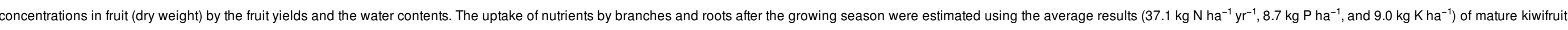

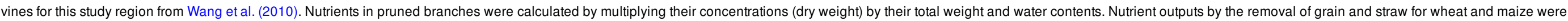
calculated according to their nutrient concentrations and the biomasses. The fallen leaves in orchards and residual straw in cropland are returned to the system and therefore were not considered within the budget.

\subsection{Statistical analysis}

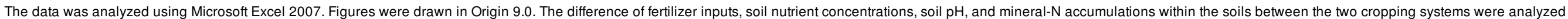




\section{elsevier_AGEE_5362}

using the Duncan multiple comparison test (SSR) at the $1 \%$ and $5 \%$ level in SAS software version 8.1 .

\section{Results}

\subsection{Nutrient input and output}

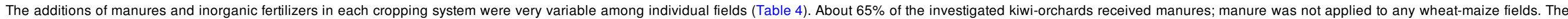

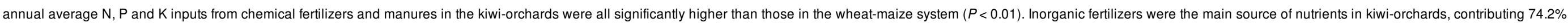
of the total $\mathrm{N}$ input, $62.7 \%$ of the total $\mathrm{P}$ input and $72.5 \%$ of the total $\mathrm{K}$ input.

Table 4 Comparisons of nutrient inputs of inorganic fertilizers and manures in kiwi-orchards (in 2012-13) and wheat and maize system in 2013.

\begin{tabular}{|c|c|c|c|c|c|c|c|c|c|}
\hline \multirow[t]{2}{*}{ Cropping system } & \multirow[t]{2}{*}{$\begin{array}{l}\text { No. of } \\
\text { Sites }\end{array}$} & \multirow[t]{2}{*}{$\begin{array}{l}\text { Descriptive } \\
\text { statistics }\end{array}$} & \multirow[t]{2}{*}{ 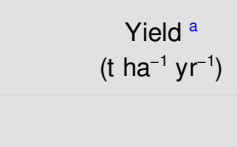 } & \multicolumn{3}{|c|}{$\begin{array}{l}\text { Inorganic fertilizer } \\
\left(\mathrm{kg} \mathrm{ha}^{-1} \mathrm{yr}^{-1}\right)\end{array}$} & \multicolumn{3}{|c|}{$\begin{array}{c}\text { Manure } \\
\left(\mathrm{kg} \mathrm{ha}^{-1} \mathrm{yr}^{-1}\right)\end{array}$} \\
\hline & & & & N & $\mathrm{P}$ & $\mathrm{K}$ & $\mathrm{N}$ & $P$ & $\mathrm{~K}$ \\
\hline \multirow[t]{3}{*}{ Kiwi- orchards } & \multirow[t]{3}{*}{242} & Average & 36.8 & 891 & 168 & 446 & 240 & 100 & 169 \\
\hline & & Range & $9.8-75.0$ & $94=3991$ & 0-1052 & 0-1591 & $0-739$ & $0-456$ & $0-873$ \\
\hline & & SD & 11.9 & 274 & 77 & 169 & 203 & 86 & 143 \\
\hline \multirow{3}{*}{$\begin{array}{l}\text { Wheat- } \\
\text { maize }\end{array}$} & \multirow[t]{3}{*}{21} & Average & 8.2 & 391 & 59 & 109 & 0 & 0 & 0 \\
\hline & & Range & $5.3-12.0$ & $211-739$ & $31-160$ & $0-249$ & 0 & 0 & 0 \\
\hline & & SD & 2.2 & 134 & 26 & 54 & 0 & 0 & 0 \\
\hline Significance & & & & ** & ** & ** & & & \\
\hline
\end{tabular}

** Significant differences $(P<0.01)$ between the two cropping systems.

${ }^{a}$ Kiwifruit yields expressed as an annual fresh fruit weight yield, and the grain yields of wheat and maize on an air-dry basis.

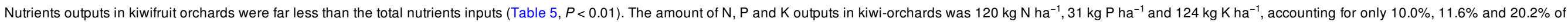

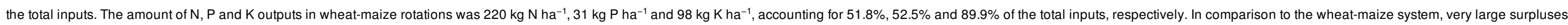
of $\mathrm{N}, \mathrm{P}$ and $\mathrm{K}$ were found in the kiwi-orchards.

Table 5 Average values (with standard deviation in brackets) for annual apparent nutrient balances in the kiwi-fruit orchard and wheat and maize systems in $\mathrm{kg} \mathrm{ha}^{-1} \mathrm{yr}^{-1}$.

\section{alt-text: Table 5}

\begin{tabular}{|c|c|c|c|c|c|c|}
\hline \multirow[t]{2}{*}{ Nutrients } & \multicolumn{2}{|c|}{ Inputs ${ }^{a}$} & \multicolumn{2}{|c|}{ Outputs ${ }^{b}$} & \multicolumn{2}{|c|}{ Surpluses $^{c}$} \\
\hline & Kiwi-orchards & Wheat-maize & Kiwi-orchards & Wheat-maize & Kiwi-orchards & Wheat-maize \\
\hline Nitrogen & $1201(285)$ & 425 (134) & $120(22)$ & 220 (32) & 1081 (274) A & 205 (49) B \\
\hline Phosphorus & $268(89)$ & $59(26)$ & $31(6)$ & $31(7)$ & 237 (76) A & 28 (5) B \\
\hline Potassium & 615 (182) & $109(54)$ & $124(36)$ & 98 (22) & 491 (169) A & 11 (8) B \\
\hline
\end{tabular}

a Inputs from chemical fertilizers, manures, deposition, irrigation and seeds.

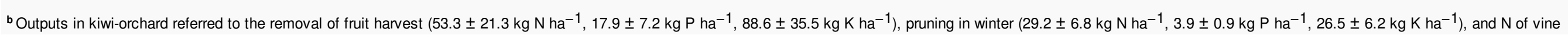




\section{elsevier_AGEE_5362}

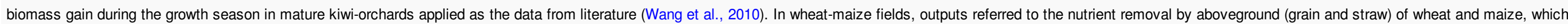
were calculated from the nutrient concentrations in each harvested component and the biomass.

${ }^{c}$ Different uppercase letters for nutrient surpluses in the two systems indicate significant differences at $P<0.01$

\subsection{Soil organic matter, total $\mathrm{N}, \mathrm{N}$ stocks, and $\mathrm{pH}$}

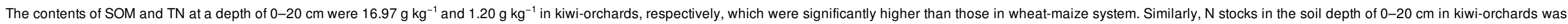
also significantly higher than that in wheat-maize fields (Table $6, P<0.01$ ). No significant difference of SOM, TN, and N stocks in the $20-40 \mathrm{~cm}$ soil depth was observed between the two systems.

Table 6 Comparison between the two cropping systems in soil organic matter (SOM) and total nitrogen (TN) at 0-20 cm and 20-40 cm depth.

alt-text: Table 6

\begin{tabular}{|c|c|c|c|c|c|c|c|}
\hline \multirow[t]{2}{*}{ Cropping system } & \multirow{2}{*}{$\begin{array}{l}\text { Descriptive } \\
\text { statistics }\end{array}$} & \multicolumn{2}{|c|}{$\mathrm{N}$ stocks $\left(\mathrm{kg} \mathrm{ha}^{-1}\right)$} & \multicolumn{2}{|c|}{$\operatorname{SOM}\left(\mathrm{g} \mathrm{kg}^{-1}\right)$} & \multicolumn{2}{|c|}{$\mathrm{TN}\left(\mathrm{g} \mathrm{kg}^{-1}\right)$} \\
\hline & & $0-20 \mathrm{~cm}$ & $20-40 \mathrm{~cm}$ & $0-20 \mathrm{~cm}$ & $20-40 \mathrm{~cm}$ & $0-20 \mathrm{~cm}$ & $20-40 \mathrm{~cm}$ \\
\hline \multirow{3}{*}{$\begin{array}{l}\text { Kiwifruit orchards } \\
(n=70)\end{array}$} & Average & 3051 & 2306 & 16.97 & 11.59 & 1.20 & 0.81 \\
\hline & Range & $1920-4915$ & $3607-1363$ & $10.98-28.73$ & $7.51-19.46$ & $0.75-1.92$ & $0.48-1.27$ \\
\hline & SD & 566 & 368 & 3.81 & 2.22 & 0.22 & 0.13 \\
\hline \multirow{3}{*}{$\begin{array}{l}\text { Wheat-maize } \\
(\mathrm{n}=21)\end{array}$} & Average & 2313 & 2129 & 10.66 & 9.88 & 0.84 & 0.73 \\
\hline & Range & $1428-3096$ & $1314-2949$ & $7.54-16.01$ & $7.50-12.97$ & $0.52-1.13$ & $0.45-1.01$ \\
\hline & SD & 511 & 446 & 1.93 & 1.30 & 0.19 & 0.15 \\
\hline Significance & & ** & ns & ** & ns & ** & ns \\
\hline
\end{tabular}

${ }^{*}$ Differences between the two systems in nutrients contents are significant at $P<0.01$. ns $=$ no significant differences.

The soil pH in 0-20 cm depth was significantly lower in kiwi-orchards than in wheat-maize fields (Fig. 3a, $P<0.05$ ); and again there was no significant difference at a depth of $20-40 \mathrm{~cm}$ (Fig. $3 \mathrm{~b}$ ).

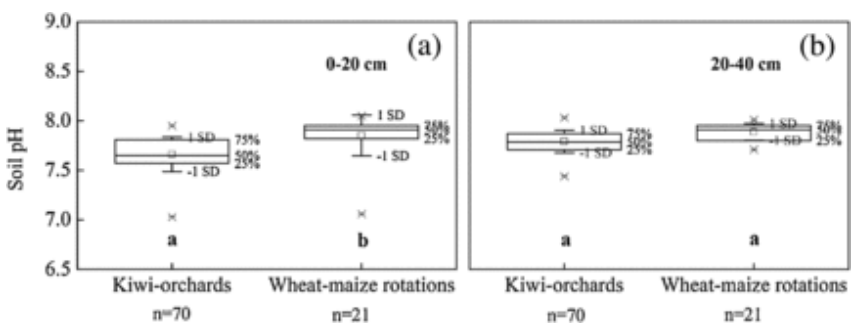

$\mathrm{n}=70 \quad \mathrm{n}=21$

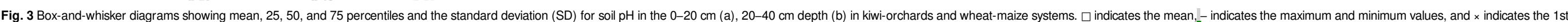
and 99th percentiles. Note :-The different bold letters in the same panel indicate significant difference at $P<0.05$.

alt-text: Fig. 3

\subsection{Mineral $\mathrm{N}$ accumulation in soil profiles}

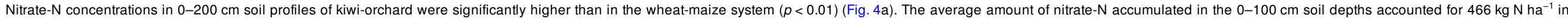
kiwi-orchards. This value was 5.9 times greater than that in wheat-maize fields $\left(79 \mathrm{~kg} \mathrm{~N} \mathrm{ha}^{-1}\right)$ (Fig. $\left.5 \mathrm{a}\right)$, and accounted for $58.7 \%$ of the total nitrate-N in the $0-200 \mathrm{~cm} \mathrm{soil} \mathrm{depths}(793 \mathrm{~kg} \mathrm{~N}$ ha-1) (Fig. $5 \mathrm{~b})$. 


\section{elsevier_AGEE_5362}
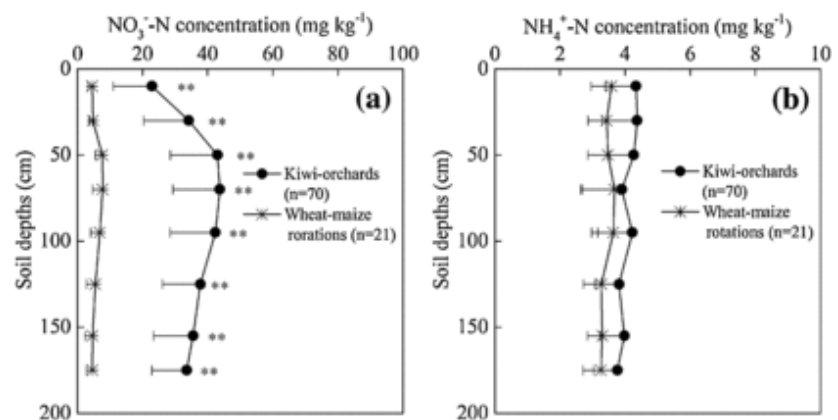

Fig. 4 Distribution of soil mineral-N in the $200 \mathrm{~cm}$ profiles of kiwi-orchards and the wheat-maize rotations. Note: atto indicates that the difference between the two systems in nutrients contents are significant at $P<0.01$. alt-text: Fig. 4

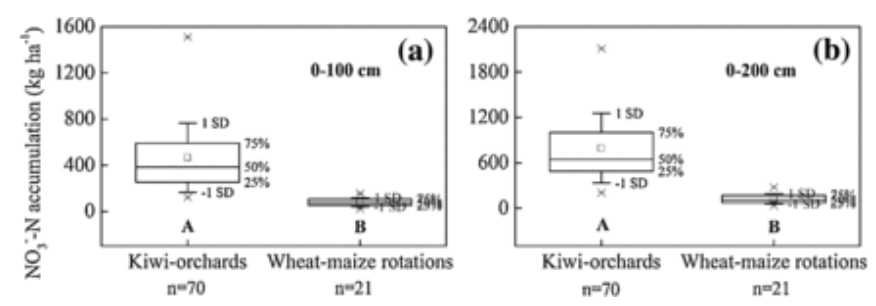

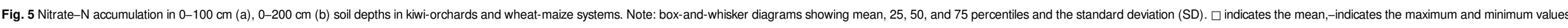
and $\mathrm{x}$ indicates the 1 st and 99 th percentiles. The different bold letters in the same panel indicate significant difference at $P<0.01$. alt-text: Fig. 5

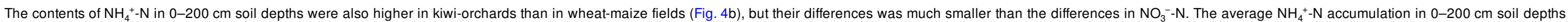
was $92.0 \mathrm{~kg} \mathrm{~N} \mathrm{ha}^{-1}$ in kiwi-orchards, compared to $71.0 \mathrm{~kg} \mathrm{~N} \mathrm{ha}^{-1}$ in wheat-maize fields (Fig. 6).
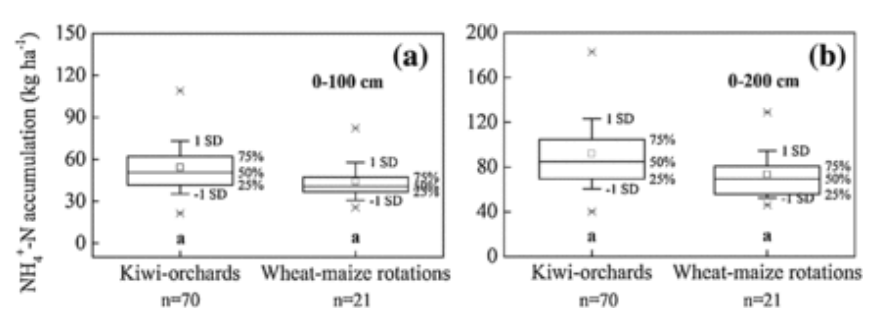

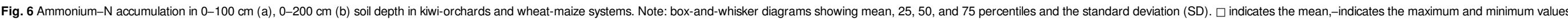
and $\mathrm{x}$ indicates the 1 st and 99 th percentiles. alt-text: Fig. 6

\subsection{Olsen-P and available-K}

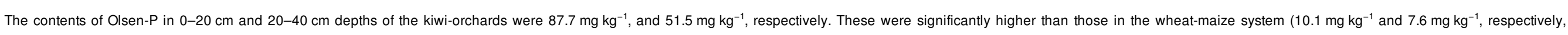
$P<0.05)$ (Fig. 7a, 7b) 


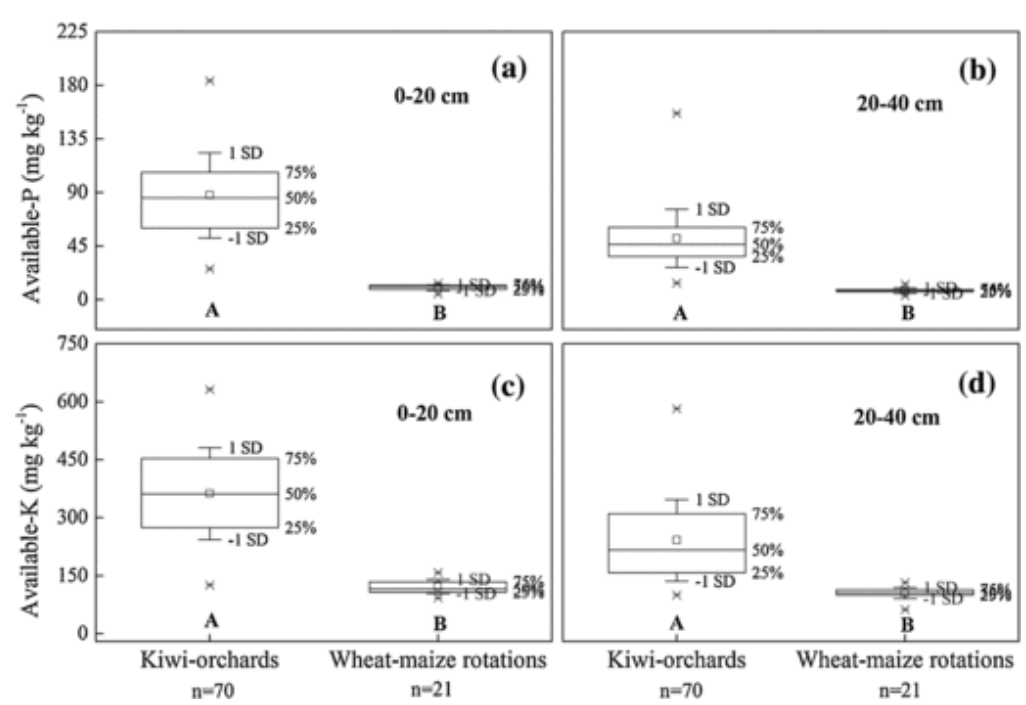

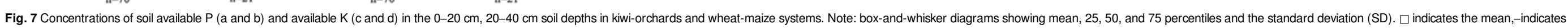
the maximum and minimum values, and $\mathrm{x}$ indicates the 1 st and 99 th percentiles. The different bold letters in the same panel indicate significant difference at $P<0.01$.

alt-text: Fig. 7

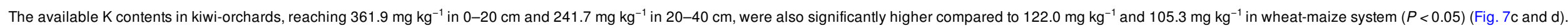

\section{Discussion}

\subsection{Nutrient budgets in the two systems}

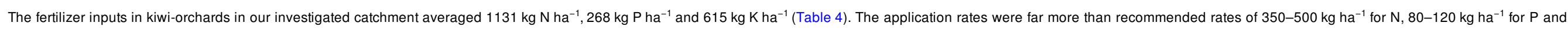

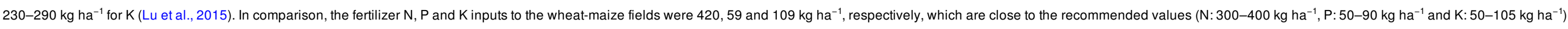

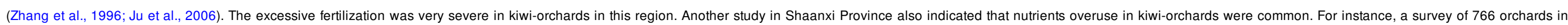

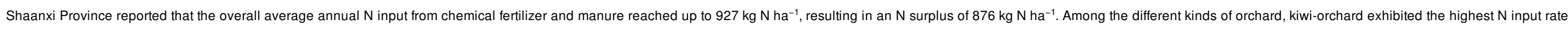
(1433 $\mathrm{kg} \mathrm{N} \mathrm{ha}^{-1}$ ) and the highest $\mathrm{N}$ surplus (1187 $\mathrm{kg} \mathrm{N} \mathrm{ha}^{-1}$ ) (Zhao et al., 2014).

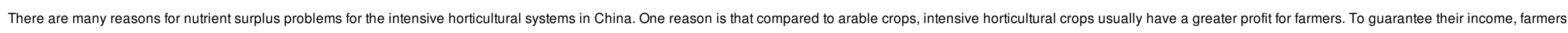

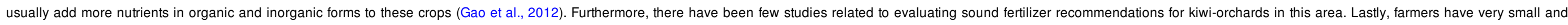
fragmented land holdings, which also result in bad nutrient management by impeding technology adoption including mechanization, which are often only viable at greater scales (Smith and Siciliano, 2015).

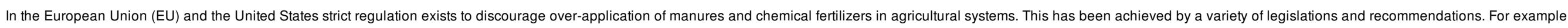

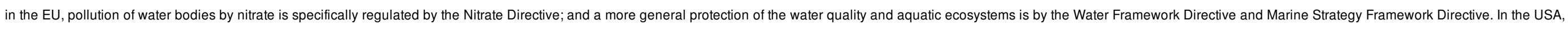

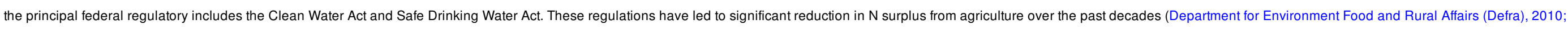

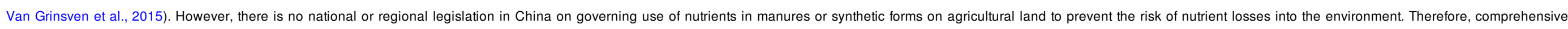
measures, including technical, economic, and social efforts, are required to solve the nutrient surplus problems in China.

\subsection{Environmental effects of land-use change from arable crops to kiwifruit orchard}

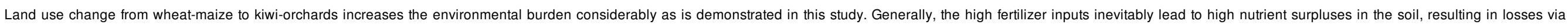




\section{elsevier_AGEE_5362}

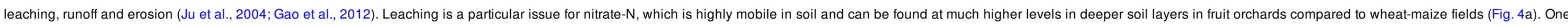

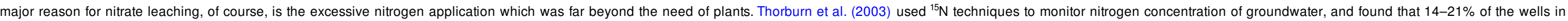

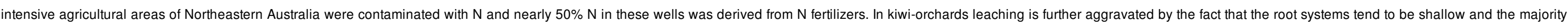

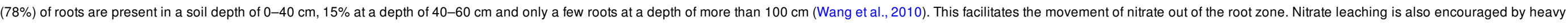

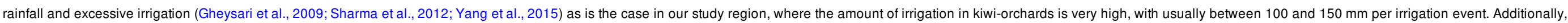

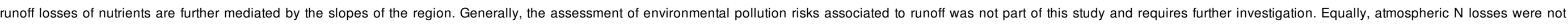
assessed, which will be a considerable pathway for $\mathrm{N}$ losses hence contributing to greenhouse gas emissions.

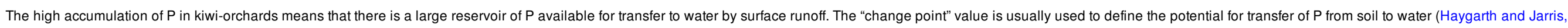

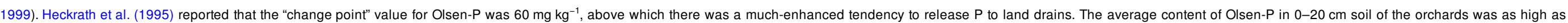
$86 \mathrm{mg} \mathrm{kg}^{-1}$ (Fig. 7a), indicating a high risk for $\mathrm{P}$ in the orchards to loss, either by runoff or leaching.

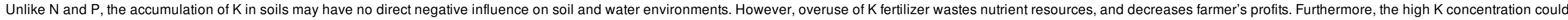

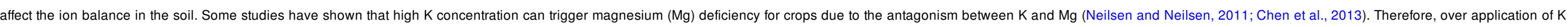
fertilizer should also be avoided.

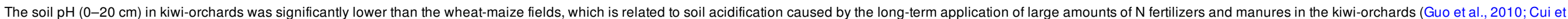
al., 2013).

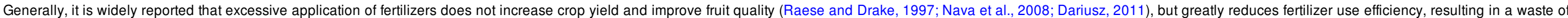

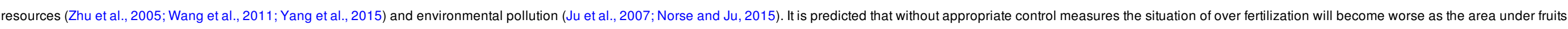
is increasing with time (Fan et al., 2010). Therefore, monitoring soil and water quality is needed to evaluate the long-term impacts of over-application nutrients in the region.

\section{Conclusions}

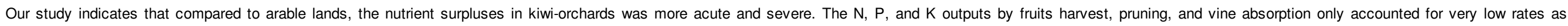

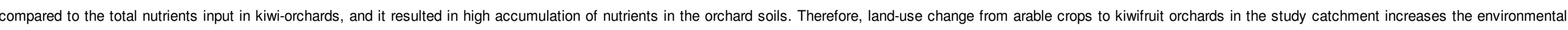

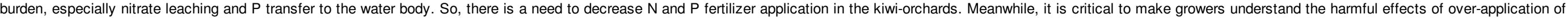

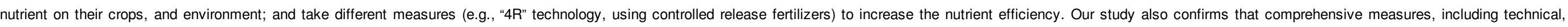
economic, and social ones, are needed to address the excessive nutrient inputs in intensive production systems.

\section{Uncited references}

Buttel (2003) and Ribaudo et al. (2001).

\section{Acknowledgments}

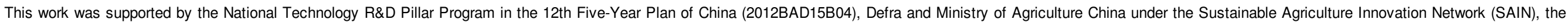
National Natural Science Foundation of China (31372137), and the 111 Project (No. B12007)

\section{References}

Buttel F.H.,-Internalizing the societal costs of agrieultural produetion, Plant Physiol. 133, 2003, 1656-1665.

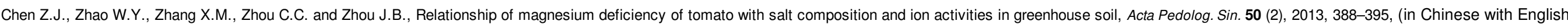
abstract). 


\section{elsevier_AGEE_5362}

Chen X.P., Zui Z.L., Fan M.S., Vitousek P., Zhao M., Ma W.Q. and Wang Z.L., Producing more grain with lower environmental costs, Nature 514, $2014,486-489$.

Cui S.H., Shi Y.L., Groffmanb Peter M., Schlesinger W.H. and Zhu Y.G., Centennial-scale analysis of the creation and fate of reactive nitrogen in China (1910-2010), Proc. Natl. Acad. Sci. U. S. A. 110, 2013, 2052-2057.

Dariusz W., The influence of nitrogen fertilization on growth, yield and fruit size of 'jonagored' apple trees, Acta Sci. Pol. Hortorum Cultus 10, 2011, 3-10.

Davidson J.E., Suddick E.C., Rice C.W. and Prokopy L.S., More food, low pollution (Mo Fo Lo Po): a grand challenge for the 21st century, J. Environ. Qual. 11, 2015, 305-311.

Department for Environment Food and Rural Affairs (Defra), Fertiliser Manual (RB209), 8th edition, 2010, TSO; Norwich.

Erisman W.J., Sutton M.A., Galloway J., Klimont Z. and Winiwarter W., How a century of ammonia synthesis changed the world, Nat. Geosci. 1, $2008,636-639$.

Fan J., Hao M.D. and Malhi S.S., Accumulation of nitrate-N in the soil profile and its implications for the environment under dryland agriculture in northern China: a review, Can. J. Soil Sci. 90, 2010, 429-440.

Gao J.J., Bai X.L., Zhou B. and Zhou J.B., Soil nutrient content and nutrient balances in newly-built solar greenhouses in northern China, Nutr. Cycl. Agroecosyst. 94, $2012,63-72$.

Gericke S. and Kurmies B., The colorimetric phosphorus analysis with ammonium-vandate-molybdate and its application in plant analysis, Plant Fertil. Soil 59, 1952, 235-247.

Gheysari M., Mirlatifi S.M., Homaee M., Asadi M.E. and Hoogenboom G., Nitrate leaching in a silage maize field under different irrigation and nitrogen fertilizer rates, Agric. Water Manage. 96, 2009, 946-954.

Guo J.H., Liu X.J., Zhang Y., Shen L., Han X., Zhang W.F., Christie P., Goulding K.W.T., Vitousek P.M. and Zhang F.S., Significant acidification in major Chinese croplands, Science 327, 2010, 1008-1010.

Haygarth P.M. and Jarris S.C., Transfer of phosphorus from agricultural soils, Adv. Agron. 66, 1999, 195-249.

Heckrath G., Brookes P.C., Poulton P.R. and Goulding K.W.T., Phosphorus leaching from soils containing different phosphorus concentrations in the broadbalk experiment, J. Environ. Qual. 24 (5), 1995, 904-910.

Ju X.T., Liu X.J., Zhang F.S. and Roelcke M., Nitrigen fertilization, soil nitrate conmmunication, and policy recommendations in several agricultural regions of China, Ambio 33, 2004 , 300-305.

Ju X.T., Kou C.L., Zhang F.S. and Christie P., Nitrogen balance and groundwater nitrate contamination: comparison among three intensive cropping systems on the North China Plain, Environ. Pollut. 143, 2006, 117-125.

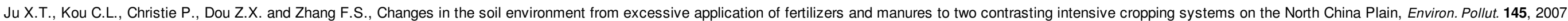
497-506.

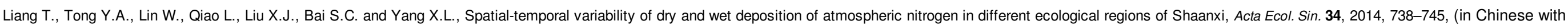
English abstract)..

Lu S.C., Yan Z.J., Chen Q. and Zhang F.S., Evaluation of conventional nitrogen and phosphorus fertilization and potential environmental risk in intensive orchards of North China, J. Plant Nutr. 35, 2012, 1509-1525.

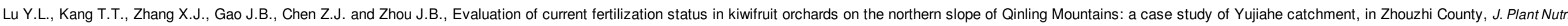
Fertil. (in Chinese with English abstract) 2015.

Nava G., Dechen A.R. and Nachtigall G.R., Nitrogen and potassium fertilization affect apple fruit quality in southern Brazil, Commun. Soil Sci. Plant Anal. 39, $2008,96-107$.

Neilsen G.H. and Neilsen D., Consequences of potassium, magnesium sulphate fertilization of high density Fuji apple orchards, Can. J. Soil Sci. 91, 2011, 1013-1027.

Norse D. and Ju X.T., Environmental costs of China's food security, Agric. Ecosyst. Environ. 209, 2015, 5-14.

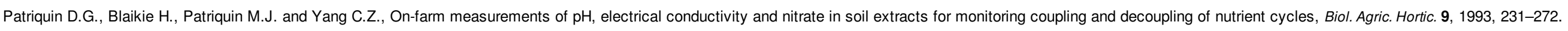

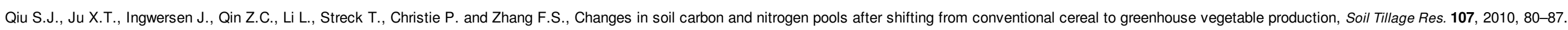

Raese J.T. and Drake S.R., Nitrogen fertilization and elemental composition affects fruit quality of 'Fuji' apples, J. Plant Nutr. 20, 1997, 1797-1809.

Ribaudo M.O., Hoag D.L.,-Smith M.E.-and Heimileh R., Environmental indiees and the polities of the Consenvation Resenve Program, Ecol. Indic. 1,2001, 11-20. 


\section{elsevier_AGEE_5362}

Sharma P., Shukla M.K., Sammis T.W., Steiner R.L. and Mexal J.G., Nitrate-nitrogen leaching from three specialty crops of new Mexico under furrow irrigation system, Agric. Water Manage. 109, 2012, 71-80.

Smith L.E.D. and Siciliano G., A comprehensive review of constraints to improved management of fertilizers in China and mitigation of diffuse water pollution from agriculture, Agric. Ecosyst. Environ. 209, 2015, 15-25.

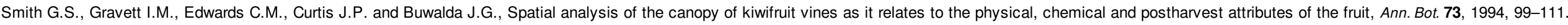

Sun Z.J. and Fu C.X., Shaanxi kiwifruit area and production rank first in world, China Fruit News 12 (26), 2009, 50, (in Chinese).

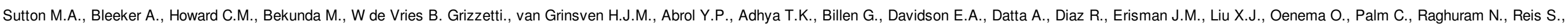
Scholz R.W., Sims T., Westhoek H. and Zhang F.S., Our Nutrient World: The Challenge to Produce More Food and Energy with Less Pollution, 2013, Center for Ecology and Hydrology; Edinburgh www.unep.org.

Thorburn P.J., Biggs J.S., Weier K.L. and Keating B.A., Nitrate in groundwater of intensive agricultural areas in coastal Northeastern Australia, Agric. Ecosyst. Environ. 94, 2003, 49-58.

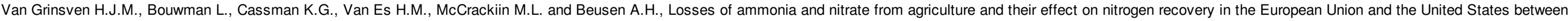
1900 and 2050, J. Environ. Qual. 44 (2), 2015, 356-367.

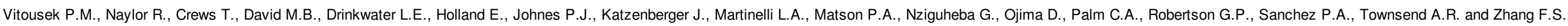

Nutrient imbalances in agricultural development, Science 324, 2009, 1519-1520.

Wang J., Tong Y.A. and Gao Y.M., Study on the roots distribution and growth dynamics of kiwifruit in Northern area of Qingling, J. Anhui Agric. Sci. 38 (15), 2010, 8085-8087, (in Chinese with English abstract).

Wang D., Xu Z.Z., Zhao J.Y., Wang Y.F. and Yu Z.W., Excessive nitrogen application decreases grain yield and increases nitrogen loss in a wheat-soil system, Acta Agric. Scand. Sect. B- Soil Plant Sci. 61, 2011, 681-692.

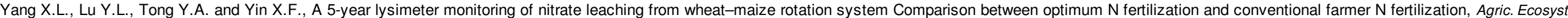

Environ. 199, 2015, 34-42

Zhang W.L., Tian Z.X., Zhang N. and Li X.Q., Nitrate pollution of groundwater in northern China, Agric. Ecosyst. Environ. 59, 1996, $223-231$.

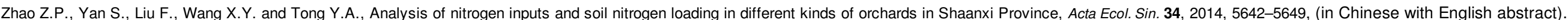

Zhu J.H., Li X.L., Christie P. and Li J.L., Environmental implications of low nitrogen use efficiency in excessively fertilized hot pepper (Capsicum frutescens L.) cropping systems, Agric. Ecosyst. Environ. 111, 2005, 70-80.

Highlights

- Nutrient budgets of kiwi-orchard and arable crop systems in a catchment were compared.

- Nutrients accumulated in soils of the two systems were determined.

- Very large surpluses of $\mathrm{N}, \mathrm{P}$ and $\mathrm{K}$ were found in the kiwi-orchards.

- High amount of nitrate-N was accumulated in deeper soil profiles of kiwi-orchards.

- Changing arable crops to orchards increased the environmental burden of the catchment.

\section{Queries and Answers}

Query: The author names have been tagged as given names and surnames (surnames are highlighted in teal color). Please confirm if they have been identified correctly Answer: They are right.

Query: Please check the email address and correct if necessary. 


\section{elsevier_AGEE_5362}

Answer: Please delete the second email address of mine (jianbinz@hotmail.com)

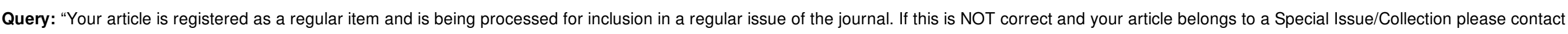
j.shanmugam@elsevier.com immediately prior to returning your corrections."

Answer: Yes, we know.

Query: This section comprises references that occur in the reference list but not in the body of the text. Please cite each reference in the text or, alternatively, delete it.

Answer: Please delete these two references.

Query: Please provide the volume and page range for Ref. "Lu et al., 2015".

Answer: This paper is in pressed. Please change "2015" to "2016 (in press)".

Query: Please check the artwork of Fig. 1 and correct if necessary.

Answer: Correct.

Query: Please check the prsentation of Tables $1-6$ and correct if necessary.

Answer: Correct. 